\title{
Productive performance of pigs in different breeding stages, housed in a Wean-to-Finish system, with several stocking rates
}

\section{Desempenho produtivo de suínos em diferentes fases de criação, alojados em sistema Wean-to-Finish, com diversas lotações}

\author{
Wagner Consoni ${ }^{*}$; Michelle de Paula Gabardo ${ }^{2}$; Juliana Lazaroto ${ }^{3}$; \\ Alencar Dante Zandonai ${ }^{4}$; Valdecir Nunes dos Santos ${ }^{4}$; \\ Sandra Davi Traverso ${ }^{5}$; André Thaler Neto ${ }^{6}$; José Cristani ${ }^{7}$
}

\begin{abstract}
The objective of the current study was to analyze the productive parameters of pigs housed in single and double capacity in the nursery, growth, and finishing phases in the Wean-to-Finish (WF) system. The research was carried out in the pig sector of the Centro de Ciências Agroveterinárias (CAV) at the Universidade do Estado de Santa Catarina (UDESC), in Lages, Santa Catarina. Ninety male castrated pigs weaned at 28 days of age and with an initial mean weight of $7.91 \mathrm{~kg}$ were used. They were housed in a WF shed and divided into two treatments: T1 with three animals per pen, $1.5 \mathrm{~m}^{2}$ of space per animal and $0.38 \mathrm{~m}$ of feeder space from weaning until slaughter; and T2 with six animals per pen, $0.75 \mathrm{~m}^{2}$ of space per animal and $0.19 \mathrm{~m}$ of feeder space in the nursery phase (up to 63 days old); and three animals per pen, with $1.5 \mathrm{~m}^{2}$ of space per animal and $0.38 \mathrm{~m}$ of feeder space for the growth and termination phases. The animals were individually weighed and the average daily feed intake (ADFI), average daily weight gain (ADWG), and feed conversion ratio (FCR) were calculated and a randomized design with a total of 10 replicate pens per treatment (with each pen considered an experimental unit) were used. Animals were slaughtered at 161 days of age. The design was completely randomized. We found no significant difference in ADWG, ADFI, or FCR in either the nursery or growth/finish phases and also found no significant difference in carcass yield. Our results show that double stocking pigs in pens is a viable alternative that allows for the best use of facilities during the nursery period on farms that use the WF system.
\end{abstract}

Key words: Breeding system. Double and single stocking. Pigs. Zootechnical performance.

\section{Resumo}

O objetivo do presente estudo foi analisar os parâmetros produtivos de suínos nas fases de creche, crescimento e terminação criados em sistema Wean-to-Finish (WF), alojados em lotações simples e dupla. A pesquisa foi realizado no setor de suinocultura do Centro de Ciências Agroveterinárias (CAV) da Universidade do Estado de Santa Catarina (UDESC), em Lages/SC. Foram utilizados 90 suínos

\footnotetext{
${ }^{1}$ M.e em Ciência Animal, Discente, Curso de Doutorado, Programa de Pós-Graduação em Ciência Animal, Universidade do Estado de Santa Catarina, UDESC, Lages, SC, Brasil. E-mail: consoni.wagner@gmail.com

${ }^{2}$ Dr $^{\mathrm{a}}$ em Ciência Animal, Universidade Federal de Minas Gerais, UFMG, Belo Horizonte, MG, Brasil. E-mail: michellegabardo@ yahoo.com.br

3 M.e em Ciência Animal, UDESC, Lages, SC, Brasil. E-mail: julianalazaroto@hotmail.com

${ }^{4}$ Médico Veterinário, UDESC, Lages, SC, Brasil. E-mail: nunes_sc@yahoo.com.br

${ }^{5} \mathrm{Dr}^{\mathrm{a}}$ em Ciências Veterinárias, Profa. Associada, UDESC, Lages, SC, Brasil. E-mail: sandra.traverso@udesc.br

6 Dr. em Ciências Agrárias, Prof. Associado, UDESC, Lages, SC, Brasil. E-mail: andre.thaler@udesc.br

7 Dr. em Zootecnia, Prof. Titular, UDESC, Lages, SC, Brasil. E-mail: jose.cristani@udesc.br

* Author for correspondence
} 
machos, castrados, desmamados com 28 dias de idade com peso médio inicial de 7,91 kg. Estes, foram alojados em galpão WF e divididos em dois tratamentos: T1, com três animais por baia, espaço de $1,5 \mathrm{~m}^{2} /$ animal e no comedouro de $0,38 \mathrm{~m}$ do alojamento até o abate; e T2, com seis animais por baia na fase de creche (até 63 dias de idade), espaço de $0,75 \mathrm{~m}^{2} /$ animal, $0,19 \mathrm{~m}$ de espaço no comedouro; e para as fases crescimento e de terminação, três animais por baia, com espaço de $1,5 \mathrm{~m}^{2} /$ animal e $0,38 \mathrm{~m}$ de espaço no comedouro. Foram realizadas pesagens individuais dos animais e calculados o consumo médio diário de ração (CMDR), o ganho médio de peso diário (GMPD) e a conversão alimentar (CA), e utilizado o delineamento ao acaso num total de dez baias de repetição por tratamento (cada baia foi considerada como uma unidade experimental). Os animais foram abatidos com idade de 161 dias. O delineamento foi inteiramente casualizado. Não houve diferença significativa nas fases referentes à creche e crescimento/terminação para GMPD, CMDR, CA e rendimento de carcaça entre os tratamentos. Por meio dos resultados conclui-se que o duplo alojamento foi uma alternativa viável para a melhor utilização das instalações no período de creche, em granjas que utilizam o sistema WF.

Palavras-chave: Alojamento simples e duplo. Desempenho zootécnico. Sistema de criação. Suínos.

\section{Introduction}

The Wean-to-Finish (WF) system is a pig breeding concept where animals remain in the same shed from weaning until the final termination phase (DHUYVETTER et al., 2014). What makes it a unique system is the adaptation of technologies used in nursery and growth/termination systems combined into a single production unit (YACENTIUK, 2007). However, in Brazil, the WF system differs from the standards present in other countries and is still in need of some adjustment, especially in the housing of piglets in the nursery phase (GABARDO et al., 2013). Due to the specific requirements of each production phase, the construction of WF sheds is $10-20 \%$ more expensive than that of conventional growth and termination sheds (WILSON, 1999).

One of the current problems of the WF system is underutilization of the shed space, which occurs in the first weeks of use by the pigs and increases the fixed costs of shed construction (BRUMM et al., 2002; PERALTA, 2008; WOLTER et al., 2002). To more efficiently use the pen space, the practice of double stocking was adopted where double the number of weaned piglets is stocked in each pen at the beginning of the housing period (WOLTER et al., 2002). In this system, when animals reach the ideal weight (i.e., at the end of the nursery phase), the groups are divided, and half are transferred to other pens inside the shed and the remaining animals are housed in conventional growth/termination units (WOLTER et al., 2002; YACENTIUK, 2007).

To determine the most efficient use of WF pens, the objective of the current study was to analyze the productive parameters of pigs in the nursery, growth, and finishing phases housed in single and double stocked pens in a WF system.

\section{Materials and Methods}

This project was approved by the Comite de Ética em Experimentação Animal (CETEA) of the CAV/UDESC of Lages/SC, protocol number 1.11.11. Ninety male, castrated pigs from the same farm, weaned at 28 days of age, with an average initial weight of $7.91 \mathrm{~kg}$ were used. Within the pens, each pig was individually identified with numbered ear rings. Piglets were housed in a WF shed, with adequate management and temperature conditions for weaning piglets. The study was divided into two periods: period 1 included weaning (28 days of age) to 63 days of age and period 2 included 63 days of age until slaughter (161 days of age). In the period 1 , animals were randomly divided into two groups, T1 (single stocking) with three animals per pen and $1.5 \mathrm{~m}^{2}$ of space per animal and T2 (double stocking) with six animals per pen and $0.75 \mathrm{~m}^{2}$ of space per animal up to 63 days of age (nursery phase). In period 2, 30 animals were removed from the double 
stocked pens and transferred to conventional growth/ termination sheds used in a multi-site system. These individuals were not evaluated following 63 days of age. Thus, both treatment groups (T1 and T2) had three animals per pen with $=1.5 \mathrm{~m}^{2}$ of space per animal in the growth/termination phases until slaughter. Ten pens per treatment were used, with each one considered an independent experimental unit.

The WF pens included compact flooring and open partitions, with net area of $4.42 \mathrm{~m}^{2}$ (3.40 m by $1.30 \mathrm{~m}$ ) and with linear feeders measuring 1.15 $\mathrm{m}$. The dimensions used in the current study are larger than those used in conventional systems because the feeder space required for subsequent phases would be insufficient if the WF pens were constructed using the dimensions recommended for a traditional nursery. The feeder space per animal for T1 was $0.38 \mathrm{~m}$ for all phases and for T2 was 0.19 $\mathrm{m}$ for the nursery phase and $0.38 \mathrm{~m}$ for the growth/ termination phases. Water was provided in the pens via adjustable height water fountains with pacifier ends. To maintain the proper temperature, the shed was lined and double curtained in addition to the natural ventilation present. During the nursery phase, 200 watt incandescent bulbs were installed approximately $1 \mathrm{~m}$ from the floor.

Throughout the experimental period, the animals had access to feed and water at will, and isoprotein and isocaloric rations formulated to meet the needs of pigs were used as described by Rostagno et al. (2005). The performance parameters analyzed were average daily feed intake (ADFI), average daily weight gain (ADWG), feed conversion ratio (FCR) and carcass yield. To obtain ADWG, the animals were weighed individually each week, from weaning to slaughter. The ADFI was calculated for each pen through the daily weighing of rations (before, and after the surplus of consumption). The animals were slaughtered at 161 days of age. The carcass yield data were obtained by evaluating back fat thickness, lean meat percentage, and warm carcass weight by using the Hennessy Grading Probe (Hennessy Grading Systems, Auckland, New Zealand) carcasstyping pistol, between the penultimate and the last rib in one of the half carcasses.

For the statistical analysis, each pen was considered an independent experimental unit, with ten replicates per treatment and a completely randomized design. Data were submitted to analysis of variance using the generalized linear models (GLMs) in SAS (SAS Institute Inc., Cary, North Caroline, USA), and were tested for normality of the residuals using the Shapiro-Wilk test (SHAPIRO; WILK, 1965). Additionally, the group means were compared using the Tukey test (5\%). Only the effect of the treatments was evaluated, as the effect of initial weight was not significant for any of the dependent variables analyzed.

\section{Results}

When comparing the mean weights of the animals in the different stages of production between the two treatments, a tendency for higher average values in the double stocking pens (T2) was observed. The mean initial weight for T1 was $7.82 \mathrm{~kg}$ and $8.00 \mathrm{~kg}$ for T2; $24.14 \mathrm{~kg}$ for T1 and $24.87 \mathrm{~kg}$ for T2 at 63 days of age; and $120.05 \mathrm{~kg}$ for T1 and 121.28 for T2 at slaughter (161 days). However, these means did not differ significantly from each other $(\mathrm{P}>0.05)$ for either the end of the nursery phase or the slaughter weight at 161 days of age. Likewise, there was also no statistical difference between the $\mathrm{T} 1$ and $\mathrm{T} 2$ groups for ADFI, ADWG, and FCR in the nursery, growth, and termination phases (Table 1).

There was also no significant difference in carcass yield between treatments $\mathrm{T} 1$ and $\mathrm{T} 2$ $(\mathrm{P}>0.05)$. Lastly, the mean back fat thickness (BFT) was $16.03 \mathrm{~cm}$ for $\mathrm{T} 1$ and $15.44 \mathrm{~cm}$ for $\mathrm{T} 2$, the lean meat percentage (LMP) was $56.04 \%$ for T1 and $57.35 \%$ for $\mathrm{T} 2$, and the warm carcass weight (WCW) was $83.14 \mathrm{~kg}$ for T1 and $86.44 \mathrm{~kg}$ for T2. 
Table 1. Average daily feed intake (ADFI), average daily weight gain (ADWG) and feed conversion ratio (FCR) of the animals during the experimental period.

\begin{tabular}{|c|c|c|c|c|}
\hline PERIOD & TREATMENT & ADFI (Kg) & ADWG (Kg) & FCR \\
\hline \multirow{3}{*}{28 - 42 days } & $\mathrm{T} 1$ & $0.448^{\mathrm{a}}$ & $0.340^{\mathrm{a}}$ & $1.32 \mathrm{a}$ \\
\hline & $\mathrm{T} 2$ & $0.411^{\mathrm{a}}$ & $0.316^{\mathrm{a}}$ & $1.30 \mathrm{a}$ \\
\hline & $P$ & $0.1085 \mathrm{NS}$ & $0.1929 N S$ & $0.5656 \mathrm{NS}$ \\
\hline \multirow{3}{*}{$28-63$ days } & $\mathrm{T} 1$ & $0.740^{\mathrm{a}}$ & $0.481^{\mathrm{a}}$ & $1.53 \mathrm{a}$ \\
\hline & $\mathrm{T} 2$ & $0.696^{\mathrm{a}}$ & $0.464^{\mathrm{a}}$ & $1.49 \mathrm{a}$ \\
\hline & $P$ & $0.1879 \mathrm{NS}$ & $0.4095 N S$ & $0.0567 N S$ \\
\hline \multirow{3}{*}{63 - 105 days } & $\mathrm{T} 1$ & $1.958^{\mathrm{a}}$ & $0.877^{\mathrm{a}}$ & $2.23 \mathrm{a}$ \\
\hline & $\mathrm{T} 2$ & $1.958^{\mathrm{a}}$ & $0.880^{\mathrm{a}}$ & $2.22 \mathrm{a}$ \\
\hline & $P$ & $1.000 \mathrm{NS}$ & $0.8624 N S$ & $0.8394 N S$ \\
\hline \multirow{3}{*}{$63-133$ days } & $\mathrm{T} 1$ & $2.200^{\mathrm{a}}$ & $0.947^{\mathrm{a}}$ & $2.30 \mathrm{a}$ \\
\hline & $\mathrm{T} 2$ & $2.190^{\mathrm{a}}$ & $0.946^{\mathrm{a}}$ & $2.32 \mathrm{a}$ \\
\hline & $P$ & $0.4351 N S$ & $0.9455 \mathrm{NS}$ & $0.6029 N S$ \\
\hline \multirow{3}{*}{$63-161$ days } & $\mathrm{T} 1$ & $2.408^{\mathrm{a}}$ & $0.984^{\mathrm{a}}$ & $2.45 \mathrm{a}$ \\
\hline & $\mathrm{T} 2$ & $2.436^{\mathrm{a}}$ & $0.981^{\mathrm{a}}$ & $2.48 \mathrm{a}$ \\
\hline & $\boldsymbol{P}$ & $0.4223 N S$ & $0.8085 N S$ & $0.3738 N S$ \\
\hline
\end{tabular}

Means with different lowercase letters differ from each other at the 0.05 level of probability by the Tukey test.

NS - not significant, $*$ - significant at $0.05(P<0.05)$.

\section{Discussion}

Our findings (Table 1) do not agree with those of other authors, who found that animals housed in double stocked pens in both a WF system and conventional nursery system, both with $0.35 \mathrm{~m}^{2}$ of space per animal, had a lower body weight of 26.9 $\mathrm{kg}$ and $27.7 \mathrm{~kg}$ respectively after 56 days of housing, than did those from lower stocked pens $\left(0.69 \mathrm{~m}^{2}\right.$ of space per animal) in a WF system (mean weight of $28.7 \mathrm{~kg}$ ) (BRUMM et al., 2002). According to these authors, the higher mean weight in the lower stocked pens was a result of these animals exhibiting better average daily weight gain and higher feed intake. The authors did not observe any difference in FCR, batch uniformity, or removal of animals owing to mortality or poor performance. One key difference to consider between the previous study and ours is that the present experiment included $0.75 \mathrm{~m}^{2}$ of space per animal in the high stocked pens and 1.5 $\mathrm{m}^{2}$ of space per animal in the low stocked pens.

Different results were also reported for another study (WOLTER et al., 2003), which evaluated density, using $0.630 \mathrm{~m}^{2}$ and $0.315 \mathrm{~m}^{2}$ of space per animal, and determined that animals housed at greater densities were lighter, with a mean weight of $58.8 \mathrm{~kg}$ in the lower density pens and a mean weight of $55.3 \mathrm{~kg}$ in the greater density pens 12 to 14 weeks post weaning. In the same study, the authors also evaluated the restriction of feeder space and found that this was advantageous for animals without restriction, which reached a mean weight of $57.6 \mathrm{~kg}$ compared to a mean weight of $56.8 \mathrm{~kg}$ in the animals with restriction within the same period. Additionally, Wolter et al. (2001) evaluated group size, using 25, 50, and 100 animals per pen, all with the same feeder space $(4.30 \mathrm{~cm}$ of space per animal $)$ and the same density $\left(0.68 \mathrm{~m}^{2}\right.$ of space per animal). The authors observed that ADWG, FCR, and body weight were similar in pigs after eight weeks of housing, with 655,648 , and 658 $\mathrm{g}$ of ADWG; 1.759, 1.755, and $1.759 \mathrm{~kg}$ of ADFI for the groups containing 25, 50, and 100 animals, respectively, and the feed conversion ratio was 0.37 for all groups. The authors also found that there was no difference in other parameters evaluated for the groups. 
In another study, a difference between pigs housed in single and double stocked pens in a WF system during the first 10 weeks after weaning was observed, with better ADWG (545 g for the single stocked and $503 \mathrm{~g}$ for the double stocked groups), as well as better ADFI ( $942 \mathrm{~g}$ as against $878 \mathrm{~g}$ ), but the FCR was similar. Despite this, they obtained similar results between groups from 10 weeks post weaning until slaughter. However, double stocking did increase the time required to reach final body weight by 2-6 days (WOLTER et al., 2002).

Regarding the carcass yield data, our results are in agreement with those of Wolter et al. (2001), where no difference in carcass yield, back fat thickness, depth and loin eye area or the lean meat percentage was found when comparing animals raised in the WF system to animals raised in the conventional system.

One important of the present study to consider is related to the space per animal used, which was above the current recommended minimum for the age of the animals, using $0.75 \mathrm{~m}^{2}$ of space in the double stocked pens and $1.5 \mathrm{~m}^{2}$ of space in the single stocked pens during the nursery phase. These values differ from the works cited by other authors, who used higher densities and consequently less space per animal in the pens.

With this study, it was observed that the initial stocking did not interfere with the productive results and carcass quality of the animals. The practice of double stocking in the WF system initially reduces the advantage of not moving and mixing the pigs, but ultimately solves the problem associated with underutilization of space in the shed (WOLTER et al., 2002). In this way, must analyze whether the transport of the animals or the underutilization of the space in the facilities exacts the greatest costs. In addition, the availability of sheds for animals to be removed to from the WF shed after the nursery phase must be considered for which need to work with the two production systems (WF and conventional multi-site system).

\section{Conclusions}

We found that double stocking is a viable alternative for the best use of the space of the facilities during the nursery period on farms that use the WF system.

\section{References}

BRUMM, M. C.; BAYSINGER, A. K.; WILLS, R. W.; THALER, R. C. Effect of wean-to-finish management on pig performance. Journal of Animal Science, Champaign, v. 80, n. 2, p. 309-315, 2002.

DHUYVETTER, K. C.; TONSOR, G. T.; TOKACH, M. D.; DRITZ, S. S.; DEROUCHEY, J. Swine weanto-finish cost-return budget. KSU Farm Management Guide, Kansas, v. 2757, p. 1-4, 2014.

GABARDO, M. P.; ZANDONAI, A. D.; CAMARGO, M. C.; GAVA, A.; CRISTANI, J.; TRAVERSO, S. D. Caracterização sanitária de suínos criados em sistema wean-to-finish. Medicina Veterinária, Recife, v. 7, n. 3, p. 23-31, 2013.

PERALTA, W. Sistema destete venta en Chile. Acta Scientiae Veterinariae, Porto Alegre, v. 36, p. 131-136, 2008. Supplement 1.

ROSTAGNO, H. S.; ALBINO, L. F. T.; DONZELE, J. L.; GOMES, P. C.; OLIVEIRA, R. F. de; LOPES, D. C.; FERREIRA, A. F.; BARRETO, S. L. T. Tabelas brasileiras para aves e suínos: composição de alimentos e exigências nutricionais. 2. ed. Viçosa, MG: UFV, 2005. $141 \mathrm{p}$.

SHAPIRO, S. S.; WILK, M. B. An analysis of variance test for normality (complete samples). Biometrika, Oxford, v. 52, n. 3-4, p. 591-611, 1965.

WILSON, K. The wean-to-finish revolution. Irving: National Hog Farmer, dec. 1999. Available at: <http:// nationalhogfarmer.com/mag/farming_weantofinish_ revolution/>. Accessed at: 3 dec. 2016.

WOLTER, B. F.; ELLIS, M.; CORRIGAN, B. P.; DEDECKER, J. M.; CURTIS, S. E.; PARR, E. N.; WEBEL, D. M. Effect of restricted postweaning growth resulting from reduced floor and feeder-trough space on pig growth performance to slaughter weight in a Weanto-finish production system. Journal of Animal Science, Champaign, v. 81, n. 4, p. 836-42, 2003. 
WOLTER, B. F.; ELLIS, M.; CURTIS, S. E.; AUGSPURGER, N. R.; HAMILTON, D. N.; PARR, E. N.; WEBEL, D. M. Effect of group size on pig performance in a wean-to-finish production system. Journal of Animal Science, Champaign, v. 79, n. 5, p. 1067-1073, 2001.

WOLTER, B. F.; ELLIS, M.; DEDECKER, J. M.; CURTIS, S. E.; HOLLIS, G. R.; SHANKS, R. D.; PARR,
E. E. N.; WEBEL, M. D. Effects of double stocking and weighing frequency on pig performance in wean-tofinish production systems. Journal of Animal Science, Champaign, v. 80, n. 6, p. 1442-1450, 2002.

YACENTIUK, M. Wean to finish concept-attracting attention. Manitoba: Manitoba Agriculture, feb. 2007. Available at: <https://www.gov.mb.ca/agriculture/ livestock/production/pork/wean-to-finish-conceptattracting-attention.html>. Accessed at: 10 mar. 2017. 